\title{
Improving Maintenance Management Practices for Building Facility
}

\author{
Zul-Atfi Ismail
}

\begin{abstract}
The practiced conventional methods for maintenance management in Malaysian Polytechnic faced many issues due to poor service delivery, inadequate finance, poor maintenance plan and maintenance backlogs. The purpose of this study is to improve the conventional method practices which tend to be ineffective in Malaysian Polytechnic. The case studies were conducted with eight Polytechnics and are selected based on conventional method practices and its major problems. There are around 32 Polytechnics in Malaysia and almost are using conventional methods. The number is considered very big indicating that the use of modern Information and Communication Technology (ICT) is still very limited compared to other institutions of higher learning in Malaysia. The overall findings of this research indicated; poor service delivery, inadequate financial, poor maintenance planning and maintenance backlogs. There is also need to overcome less man power competencies of maintenance management practices which existed with all eight Polytechnics. The proposed system is intended to be used for maintenance management practices at Malaysian Polytechnics in order to provide high-quality of building facility with safe and healthy environments.
\end{abstract}

\section{Keywords: Maintenance Management, Conventional Method, Maintenance Management System, Malaysian Polytechnic}

\section{OVERVIEW OF MAINTENANCE MANAGEMENT}

\section{A. The Need for Maintenance Management}

Maintenance is a continuous operation to keep building, infrastructure, and equipment in the best form for normal use [1]. It is also to ensure the facilities are in a good condition for a life time. In achieving the sustainability of facilities condition, maintenance management required the efficiency and effectiveness for strategic planning. There are many existing theories, models and framework related to maintenance management. According to [2], maintenance management system used conventional method in many university campuses in Malaysia. The system is using paper-based form to provide defect report from student and staff. Meanwhile, improper database such as Microsoft Excel and Microsoft Word database contribute to the irregularities in the university's maintenance management system. The lack of comprehensive maintenance management also is due to not providing the decision making process to solve complicated problems of building and infrastructure defect. Therefore, a computerised maintenance management system (CMMS) is the suggested solution for that problem in Malaysian university.

According to [3], the management system implemented by Polytechnic is also using the conventional method. Polytechnic has the department to coordinate maintenance and repair of equipment, buildings, infrastructure and facilities related work, including support services at Polytechnic. There was a related problem on handling facility maintenance at Tuanku Sultanah Bahiyah Polytechnic [4]. Commonly, they use phone, paper-based form and email to report the defects of building facilities.
The phone application for defect reports depends on involved party in maintenance management. If one of the party is not available, the defect reports cannot be made and need to be reported again another time. Meanwhile, paper-based form requires the signature from the head of department before being submitted to the maintenance management staffs. This process would take a few days before the problem could be attended. Complaint via email sometimes causes problem to the recipient due to the difficulty to receive the defect complaint because the mailbox is occupied. In fact, the facility handling is uniformly practiced at most Malaysian Polytechnics [3]. The implementation of conventional method provides ineffective and poorly organised maintenance management [5]. The losses incurred by breakdowns or failures of operating system, for example, electrical and mechanical utilities. Besides, the ineffective maintenance management let the unhanding of preventive maintenance [6]. Therefore, maintenance management system is necessary to handle the facilities defect in a more appropriate, time saving and paperless manner.

\section{B. Technologies in Maintenance Management}

According to [7], the problem of maintenance management also happened at the critical building such as hospital that is full with patients and other facilities. There is no quality control system and preventive maintenance whilst the technical manuals such as electrical utilities services policy are not fully utilised when repairs are made as maintenance on the medical equipment which is not done on the stipulated time frame. Thus, the new approach of in-house Computerised Maintenance Management System (CMMS) is applied to reduce accumulation of

\footnotetext{
${ }^{1}$ Zul-Atfi Ismail, School of Environmental Engineering, Universiti Malaysia Perlis, 02600 Arau, Perlis, Malaysia, zulatfippkas@ gmail.com (*Corresponding Author)
} 
paper work in the office and proper monitoring of the equipment. The system solves the faults in the shortest duration and to report the possible personnel for handling the equipment. In addition, there is lots of maintenance software which are widely used. The softwares are able to record and process data for future maintenance references, such as Computer-Aided Facilities Management (CAFM), Integrated Workplace Management System (IWMS) and Facility Management Information System (FMIS). Presently, CMMS application is broadly used in maintenance management processes for building facilities. CMMS can reduce the negligent management due to problems emerging as a result of the need to manage huge and complicated data, for instance, data loss caused by unsuitable places for file storage and excessive retrieval time in the recovery of data files [8].The application of CMMS is practiced in many sectors such as construction maintenance and facility management industry. At the same time, [9] emphasised that this software lacks of any decision analysis support for maintenance management. CMMS can only offer analysis of data recorded for decision requirement.

A new model has been proposed based on combining the Analytic Hierarchy Process (AHP) and Fuzzy Logic (FL) control to produce a "Decision Making Grid". This combination provides features of both fixed rules and flexible strategies. The grid supports the making of decision about how facilities should be maintained. The model also proposed the condition assessment for the building and infrastructure maintenance and provides the priority of facilities which to be maintained first. Meanwhile, [10] suggested Just in Time \& Cost Effective Maintenance (JIT DMAINT) framework for new innovative system as conventional method lack in providing accurate maintenance decisions. By using the strategies operation in JIT DMAINT, the system can reduce failures appreciably, prolongs the life length of equipment and perform profitable maintenance to the organisation.

In addition, safety risk in the maintenance assessment for providing decision making process is the main issue at high-rise buildings such as to monitor the facilities of a flat house which has been decorated with mosaic tiles at the exterior wall. The Non-Destructive Testing (NDT) probably is a way to improve maintenance management to avoid accident at the construction site. NDT improve the maintenance effectiveness by reducing the cost and time for the inspection of a building [11]. Nevertheless, the traditional approach of installing scaffoldings or deploying manned gondolas to carry out periodic manual checking and inspection for high-rise building is susceptible to human fatigue and time inconsistency. There should be an assistance of robot to be applied together with the NDT. The robotic instruments with NDT increase the value of maintenance project in inspection operation [12]. Furthermore, the latest techniques system for maintenance management is extended today by using scientific instruments such as Infrared Thermo Graphic Test (IRT),
Ground Penetrating Radar (GPR) and Laser Induced Breakdown Spectroscopy (LIBS) to reduce the problems of maintenance management [13].

\section{ISSUES OF MAINTENANCE MANAGEMENT AT POLYTECHNIC}

Many buildings and infrastructures need to be refurbished to enhance the effectiveness in maintenance management processes [14]. The conventional method has to be improved for better maintenance of building and infrastructure, and to provide good environments. The technical and managerial defects are the domain of problems on conventional method in maintenance management. The technical defect is the lack of technical expert to operate and monitor the facilities of building and infrastructure with new technology. This is related to the unexposed knowledge in Information and Communication Technology (ICT) by using computerised systems. Presently, Computerised Maintenance Management System (CMMS) application is wide used in maintenance management processes of building facility. CMMS can reduce the negligent management due to problems emerging as a result of the need to manage huge and complicated data. For instance, data loss caused by unsuitable places for file storage and excessive retrieval time in the recovery of data files [5].

The managerial defect consists of project management, resource management, economical and financial defects [15]. The project management defects are improper planning of works, inefficient system to record data, failure to identify the potential defect causes, and specified the correct remedial work. The uses of paper-based form in reporting defects are rudimentary and haphazard. As a matter of fact, the docket information like a daily report is not reliable and not all the works are implemented. Therefore, it's difficult to assess decision making for remedial works due to maintenance planning [16]. The resource management defect is related to the poor workmanship. The technicians who involved in maintenance management should be trained with technical skills to complete tasks efficiently. The technician's competencies will ensure the quality of maintenance management provided at Polytechnic [17]. The economical and financial defects are definite as an insufficient budget to conduct maintenance management in the organization. For instance, even if all the work is carried out correctively, it still requires some more systematic system and costeffective approaches than the conventional processes currently in use at Malaysian Polytechnic.

Maintenance management at Polytechnic revealed a number of shortcomings as it still use paper-based form and unsystematic database to manage a complex and huge amounts of data including data analysis and tracking of complaints. Thus, the new system is proposed in order to improve the conventional method that tends to be cumbersome at Polytechnic [5]. Essentially, the new system has the potential to transform maintenance 
management processes to foster the professionalism and excellent working culture for successful transformation agenda.

\section{METHODOLOGY}

\section{A. Case Study}

Case study research method was selected for acquiring more insight into the maintenance management problems and current practices of maintenance of building facilities at the Polytechnics. The ICT implementation in the maintenance management processes was also explored to gain the skills level on the ICT implementation between staffs in the particular cases. In addition, they were used to identify the data generalisation that inter-related with the literature studies. The justification to use a case study approach and the adoption of multiple case studies design is due to the involvement of extensive data collection in understanding the entire knowledge, processes and to discover the explicit findings from the critical cases. Even the 'generalisability' of case studies can be increased by strategic selection of cases for the data collection [18].

The case studies involved eight Polytechnics (Case A to Case $\mathrm{H})$ to investigate the maintenance management practices in each Polytechnics. The data was collected by semi-structured interviews with those responsible parties (e.g. engineers and assistant engineers) for maintenance management at the Polytechnics. The first part of thee interview described the background information of the respondents and contact details. Meanwhile, the second part consists of four sections to analyze the major problems, approaches to addressing problems, ICT implementation, and maintenance management system at the Polytechnics.

For the purpose of this research, the 'unit of analysis' is geared towards achieving the research objectives which is to investigate the current practices on the maintenance management processes at the Polytechnics. The 'unit of analysis' for this research is based on four 'embedded units of analysis' as follows:

- Maintenance management problems: This explores the major problems on the maintenance management practices at Polytechnic.

- Approaches to address problems: This aimed to reduce the problems that involved in the maintenance operations.

- ICT implementation: This sought to identify the current technology of ICT tools to improve the particular maintenance processes at the Polytechnics.

- Maintenance management systems: This sought to identify the maintenance procedures at the Polytechnics.

Data analysis involved cross-case analyses as shown in F igure I.

The multiple units of analysis (embedded) designs were conducted due to the significant role in allowing more

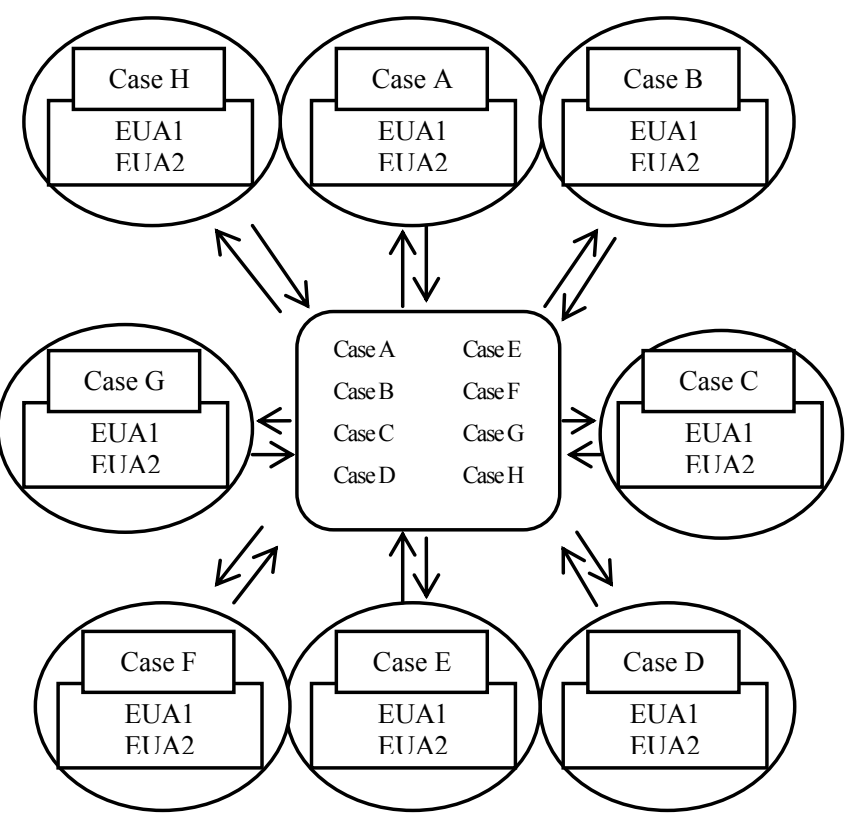

Key

EUA1 Embedded Unit of Analysis 1: Maintenance Management Problems

EUA2 Embedded Unit of Analysis 2: Approaches to Address Problems

EUA3 Embedded Unit of Analysis 3: ICT Implementation

EUA4 Embedded Unit of Analysis 4: Maintenance Management System

FIGURE I

CROSS CASE ANALYSIS (SOURCE: [9])

sensitivity to the case studies questions compared by using holistic approach. The selection case studies was to capture the information on the current practices of maintenance management, problems, current approaches and the ICT implementation on maintenance management processes. The cross-case analysis is required to increase the generalisability of study [20]. In addition, the advantages of this approach are it can replicate the findings from one case study to another [21]. The current case studies involved the investigation of four 'embedded unit of analysis' to provide the key findings from the contrary explanation. The summary of the case studies findings (grouped according to the four main 'embedded unit of analysis) are discussed in the following section.

\section{B. Case Studies Projects}

The case studies on the eight Polytechnics were undertaken in order to identify the maintenance management problems, the current approaches to addressing the problems and the ICT implementation and the maintenance management system to obtain information relating to the maintenance identification, assessment, planning and execution processes. Those Polytechnics are selected based on major problems of using conventional 
method in the comparison to investigate the maintenance management practices in each Polytechnic. There are total 32 Polytechnics in Malaysia using conventional method and inadequately use of modern ICT tools compared to other institutions of higher learning (e.g. Universiti Sains Malaysia) and is presented in Table I [22].

TABLE I

LIST OF POLYTECHNICS

\begin{tabular}{|c|c|c|c|c|}
\hline No & Name of Polytechnic & $\begin{array}{l}\text { Type of } \\
\text { Polytechnic }\end{array}$ & $\begin{array}{l}\text { Maintenance } \\
\text { Management } \\
\text { System } \\
\end{array}$ & $\begin{array}{l}\text { Case } \\
\text { Study }\end{array}$ \\
\hline 1 & $\begin{array}{l}\text { Ibrahim Sultan } \\
\text { Polytechnic, Johor }\end{array}$ & Premier & Conventional & $\sqrt{ }$ \\
\hline 2 & $\begin{array}{l}\text { Sultan Salahuddin } \\
\text { Abdul Aziz Shah } \\
\text { Polytechnic, } \\
\text { Selangor }\end{array}$ & Premier & Conventional & $\sqrt{ }$ \\
\hline 3 & $\begin{array}{l}\text { Ungku Omar } \\
\text { Polytechnic, Perak }\end{array}$ & Premier & Conventional & - \\
\hline 4 & $\begin{array}{l}\text { Sultan Haji Ahmad } \\
\text { Shah Polytechnic, } \\
\text { Pahang }\end{array}$ & Old & Conventional & - \\
\hline 5 & $\begin{array}{l}\text { Sultan Abdul Halim } \\
\text { Mu'adzam Shah, } \\
\text { Kedah }\end{array}$ & Old & Conventional & - \\
\hline 6 & $\begin{array}{l}\text { Kota Bharu } \\
\text { Polytechnic, } \\
\text { Kelantan } \\
\end{array}$ & Old & Conventional & - \\
\hline 7 & $\begin{array}{l}\text { Kuching Sarawak } \\
\text { Polytechnic, } \\
\text { Sarawak }\end{array}$ & Old & Conventional & - \\
\hline 8 & $\begin{array}{l}\text { Port Dickson } \\
\text { Polytechnic, Negeri } \\
\text { Sembilan }\end{array}$ & Old & Conventional & $\sqrt{ }$ \\
\hline 9 & $\begin{array}{l}\text { Kota Kinabalu } \\
\text { Polytechnic, Sabah }\end{array}$ & Old & Conventional & - \\
\hline 10 & $\begin{array}{l}\text { Seberang Perai } \\
\text { Polytechnic, Pulau } \\
\text { Pinang }\end{array}$ & Old & Conventional & - \\
\hline 11 & $\begin{array}{l}\text { Melaka Polytechnic, } \\
\text { Melaka }\end{array}$ & Old & Conventional & $\sqrt{ }$ \\
\hline 12 & $\begin{array}{l}\text { Kuala Terengganu } \\
\text { Polytechnic, } \\
\text { Terengganu } \\
\end{array}$ & Old & Conventional & - \\
\hline 13 & $\begin{array}{l}\text { Sultan Mizan Zainal } \\
\text { Abidin Polytechnic, } \\
\text { Terengganu }\end{array}$ & Old & Conventional & - \\
\hline 14 & $\begin{array}{l}\text { Merlimau } \\
\text { Polytechnic, Melaka }\end{array}$ & Old & Conventional & $\sqrt{ }$ \\
\hline 15 & $\begin{array}{l}\text { Sultan Azlan Shah } \\
\text { Polytechnic, Perak }\end{array}$ & New & Conventional & - \\
\hline 16 & $\begin{array}{l}\text { Tuanku Sultanah } \\
\text { Bahiyah } \\
\text { Polytechnic, Kedah }\end{array}$ & New & Conventional & - \\
\hline 17 & $\begin{array}{l}\text { Sultan Idris Shah } \\
\text { Polytechnic, } \\
\text { Selangor } \\
\end{array}$ & New & Conventional & - \\
\hline 18 & $\begin{array}{l}\text { Tuanku Syed } \\
\text { Sirajuddin } \\
\text { Polytechnic, Perlis }\end{array}$ & New & Conventional & - \\
\hline 19 & $\begin{array}{l}\text { Muadzam Shah } \\
\text { Polytechnic, Pahang }\end{array}$ & New & Conventional & - \\
\hline 20 & $\begin{array}{l}\text { Mukah Polytechnic, } \\
\text { Sarawak }\end{array}$ & New & Conventional & - \\
\hline 21 & $\begin{array}{l}\text { Balik Pulau } \\
\text { Polytechnic, Pulau } \\
\text { Pinang }\end{array}$ & New & Conventional & - \\
\hline
\end{tabular}

\begin{tabular}{c|l|l|l|c}
\hline 22 & $\begin{array}{l}\text { Jeli Polytechnic, } \\
\text { Kelantan }\end{array}$ & New & Conventional & - \\
\hline 23 & $\begin{array}{l}\text { Nilai Polytechnic, } \\
\text { Negeri Sembilan }\end{array}$ & New & Conventional & $\sqrt{ }$ \\
\hline 24 & $\begin{array}{l}\text { Banting Polytechnic, } \\
\text { Selangor }\end{array}$ & New & Conventional & $\sqrt{ }$ \\
\hline 25 & $\begin{array}{l}\text { Mersing } \\
\text { Polytechnic, Johor }\end{array}$ & New & Conventional & $\sqrt{ }$ \\
\hline 26 & $\begin{array}{l}\text { Hulu Terengganu } \\
\text { Polytechnic, } \\
\text { Terengganu }\end{array}$ & New & Conventional & - \\
\hline 27 & $\begin{array}{l}\text { Sandakan } \\
\text { Polytechnic, Sabah }\end{array}$ & New & Conventional & - \\
\hline 28 & $\begin{array}{l}\text { Metro KL } \\
\text { Polytechnic, Kuala } \\
\text { Lumpur }\end{array}$ & New & Conventional & - \\
\hline 29 & $\begin{array}{l}\text { Metro Kuantan } \\
\text { Polytechnic, Pahang }\end{array}$ & New & Conventional & - \\
\hline 30 & $\begin{array}{l}\text { Metro Johor Bahru } \\
\text { Polytechnic, Johor }\end{array}$ & New & Conventional & - \\
\hline 31 & $\begin{array}{l}\text { Metro Betong } \\
\text { Polytechnic, } \\
\text { Sarawak }\end{array}$ & New & Conventional & - \\
\hline 32 & $\begin{array}{l}\text { Metro Tasek } \\
\text { Gelugor Polytechnic, } \\
\text { Pulau Pinang }\end{array}$ & New & Conventional & - \\
\hline
\end{tabular}

The interviews consisted of three types of Polytechnic, namely, 'New Polytechnic', 'Old Polytechnic' and 'Premier Polytechnic'. The case study was based on eight cases (Case A-Case H) of Polytechnic in Malaysia. There were two case studies (Case A and B) on 'Premier Polytechnic' under the transformation plan to become a University College by 2015 and three case studies (Case C, D, and E) on 'Old Polytechnic' due to older establishment and operation such as the Melaka Polytechnic which was established in January 1999. In addition, three more case studies (Case F, G, and H) were classified as 'New Polytechnic' which manages the maintenance operation with fully equipped new amenities and facilities.

The justifications for the selected case studies were according to the following main criteria; (1) exposed to the conventional method used and major problems, (2) attempted to implement computerised technology and (3) the willingness of staff to share their experiences in improving the maintenance management processes at the Polytechnic. The different types of Polytechnics was to provide variations on the maintenance management practices classified as old, new and premier Polytechnic respectively. The professional staff were interviewed which included engineer or assistant engineer and had the experiences in the maintenance management practices. The summary on the eight case studies is presented in Table II.

The semi-structured interviews were conducted with the engineers or assistant engineers who were responsible for the maintenance management of the entire Polytechnic's building facility under the Facility Management and Development Unit (UPPF) and Maintenance and Development Unit (UPS). The interview sessions took around half an hour to accumulate the data on the maintena nce processes including the demonstration of the current 
TABLE II

LIST OF CASE STUDIES

\begin{tabular}{|c|c|c|c|c|}
\hline Case & $\begin{array}{l}\text { Name of } \\
\text { Polytechnic }\end{array}$ & $\begin{array}{l}\text { Type of } \\
\text { Polytechnic }\end{array}$ & $\begin{array}{l}\text { Person } \\
\text { Interviewed }\end{array}$ & $\begin{array}{l}\text { Maintenance } \\
\text { Management } \\
\text { System }\end{array}$ \\
\hline A & $\begin{array}{l}\text { Ibrahim } \\
\text { Sultan } \\
\text { Polytechnic, } \\
\text { Johor } \\
\end{array}$ & Premier & Engineer & Conventional \\
\hline B & $\begin{array}{l}\text { Sultan } \\
\text { Salahuddin } \\
\text { Abdul Aziz } \\
\text { Shah } \\
\text { Polytechnic, } \\
\text { Selangor } \\
\end{array}$ & Premier & $\begin{array}{l}\text { Assistant } \\
\text { Engineer }\end{array}$ & Conventional \\
\hline $\mathrm{C}$ & $\begin{array}{l}\text { Port Dickson } \\
\text { Polytechnic, } \\
\text { Negeri } \\
\text { Sembilan } \\
\end{array}$ & Old & $\begin{array}{l}\text { Assistant } \\
\text { Engineer }\end{array}$ & Conventional \\
\hline D & $\begin{array}{l}\text { Melaka } \\
\text { Polytechnic, } \\
\text { Melaka }\end{array}$ & Old & $\begin{array}{l}\text { Assistant } \\
\text { Engineer }\end{array}$ & Conventional \\
\hline E & $\begin{array}{l}\text { Merlimau } \\
\text { Polytechnic, } \\
\text { Melaka }\end{array}$ & Old & Engineer & Conventional \\
\hline F & $\begin{array}{l}\text { Mersing } \\
\text { Polytechnic, } \\
\text { Johor }\end{array}$ & New & $\begin{array}{l}\text { Assistant } \\
\text { Engineer }\end{array}$ & Conventional \\
\hline G & $\begin{array}{l}\text { Banting } \\
\text { Polytechnic, } \\
\text { Selangor }\end{array}$ & New & $\begin{array}{l}\text { Assistant } \\
\text { Engineer }\end{array}$ & Conventional \\
\hline $\mathrm{H}$ & $\begin{array}{l}\text { Nilai } \\
\text { Polytechnic, } \\
\text { Negeri } \\
\text { Sembilan }\end{array}$ & New & $\begin{array}{l}\text { Assistant } \\
\text { Engineer }\end{array}$ & Conventional \\
\hline
\end{tabular}

maintenance management system with the implementation of the ICT tools by the assistant engineer. All the data from the interviews were recorded using video camera and transcribed verbatim

Based on the case studies, the Nilai Polytechnic recorded the highest major problems on the maintenance management processes and are summarised together with other elements of analysis in Table III below.

TABLE III

CROSS-CASE ANALYSIS

\begin{tabular}{|c|c|}
\hline Case & $\begin{array}{l}\text { Element of Analysis: Maintenance Management } \\
\text { Problems }\end{array}$ \\
\hline Case A & $\begin{array}{l}\text { - Nonspecific complaint } \\
\text { - Time gap of building repairs } \\
\text { - Limited budgets } \\
\text { - Less competent manpower } \\
\text { - Defects repetition } \\
\text { - Student vandalism }\end{array}$ \\
\hline Case B & $\begin{array}{l}\text { - Less competent manpower } \\
\text { - Defects repetition } \\
\text { - Time gap of building repairs } \\
\text { - Limited budgets }\end{array}$ \\
\hline Case C & $\begin{array}{l}\text { - Nonspecific complaint } \\
\text { - Time gap of building repairs } \\
\text { - Limited budgets } \\
\text { - Less competent manpower } \\
\text { - Defects repetition }\end{array}$ \\
\hline Case D & $\begin{array}{l}\text { - Less competent manpower } \\
\text { - Defects repetition }\end{array}$ \\
\hline
\end{tabular}

\begin{tabular}{|c|c|}
\hline & $\begin{array}{l}\text { - Time gap of building repairs } \\
\text { - Student vandalism }\end{array}$ \\
\hline Case E & $\begin{array}{l}\text { - Limited budgets } \\
\text { - Defects repetition } \\
\text { - Student vandalism } \\
\end{array}$ \\
\hline Case F & $\begin{array}{l}\text { - Less competent manpower } \\
\text { - Defects repetition } \\
\text { - Time gap of building repairs } \\
\text { - Limited budgets }\end{array}$ \\
\hline Case G & $\begin{array}{l}\text { - Verbal complaint } \\
\text { - Unsystematic database } \\
\text { - Defects repetition } \\
\text { - Less competent manpower } \\
\text { - Time gap of building repairs } \\
\text { - Limited budgets } \\
\text { - Poor quality contractor }\end{array}$ \\
\hline Case $\mathrm{H}$ & $\begin{array}{l}\text { - Lack of motivation for reporting defect } \\
\text { - Delayed complaint delivery } \\
\text { - Undelivered complaint } \\
\text { - Limited budgets } \\
\text { - Nonspecific complaint } \\
\text { - Time gap of building repairs } \\
\text { - Defects repetition } \\
\text { - Poor quality contractor } \\
\end{array}$ \\
\hline Case & Element of Analysis: Approaches to Address Problems \\
\hline Case A & $\begin{array}{l}\text { - To replace the old material (e.g. timber) with the strong } \\
\text { material (e.g. heavy steel) } \\
\text { - Allocated the budget and punishment for vandalism } \\
\text { cases } \\
\text { - Training courses for technician }\end{array}$ \\
\hline Case B & $\begin{array}{l}\text { - Training courses for technician } \\
\text { - To replace the old material (e.g. timber) with the strong } \\
\text { material (e.g. heavy steel) }\end{array}$ \\
\hline Case $\mathrm{C}$ & $\begin{array}{l}\text { - Training courses for technician } \\
\text { - To replace the old material (e.g. timber) with the strong } \\
\text { material (e.g. heavy steel) }\end{array}$ \\
\hline Case D & $\begin{array}{l}\text { - Provide more frequent inspection and assessment in } \\
\text { identifying the causes of defect } \\
\text { - Training courses for technician } \\
\text { - Installed the signage to motivate student for conserving } \\
\text { facility }\end{array}$ \\
\hline Case E & $\begin{array}{l}\text { - Priority on maintenance repairs } \\
\text { - Installed the signage to motivate student for conserving } \\
\text { facility }\end{array}$ \\
\hline Case F & - Training courses for technician \\
\hline Case G & $\begin{array}{l}\text { - Issued notice to prevent the verbal complaint for minor } \\
\text { defect } \\
\text { - Improve the maintenance assessment for the building } \\
\text { works did by main contractor } \\
\text { - Training courses for technician }\end{array}$ \\
\hline Case $\mathrm{H}$ & $\begin{array}{l}\text { - Improve the maintenance assessment for the building } \\
\text { works did by main contractor }\end{array}$ \\
\hline Case & Element of Analysis: ICT Implementation \\
\hline Case A & $\begin{array}{l}\text { - mySPATA- Data inventory for immobile facilities (e.g. } \\
\text { building) } \\
\text { - mySPA- Data inventory for mobile facilities (e.g. } \\
\text { furniture) }\end{array}$ \\
\hline Case B & $\begin{array}{l}\text { - mySPATA- Data inventory for immobile facilities (e.g. } \\
\text { building) } \\
\text { - mySPA- Data inventory for mobile facilities (e.g. } \\
\text { furniture) }\end{array}$ \\
\hline
\end{tabular}




\begin{tabular}{|c|c|}
\hline & - Email System- for managing complaints \\
\hline Case C & $\begin{array}{l}\text { - mySPATA- Data inventory for immobile facilities (e.g. } \\
\text { building) } \\
\text { - mySPA- Data inventory for mobile facilities (e.g. } \\
\text { furniture) } \\
\text { - Email System- for managing complaints }\end{array}$ \\
\hline Case D & $\begin{array}{l}\text { - mySPATA- Data inventory for immobile facilities (e.g. } \\
\text { building) } \\
\text { - mySPA- Data inventory for mobile facilities (e.g. } \\
\text { furniture) } \\
\text { - E-Aduan System- for managing complaints }\end{array}$ \\
\hline Case E & $\begin{array}{l}\text { - mySPATA- Data inventory for immobile facilities (e.g. } \\
\text { building) } \\
\text { - mySPA- Data inventory for mobile facilities (e.g. } \\
\text { furniture) }\end{array}$ \\
\hline Case F & $\begin{array}{l}\text { - mySPATA- Data inventory for immobile facilities (e.g. } \\
\text { building) } \\
\text { - mySPA- Data inventory for mobile facilities (e.g. } \\
\text { furniture) }\end{array}$ \\
\hline Case G & $\begin{array}{l}\text { - mySPATA- Data inventory for immobile facilities (e.g. } \\
\text { building) } \\
\text { - mySPA- Data inventory for mobile facilities (e.g. } \\
\text { furniture) } \\
\text { - Email System- for managing complaints }\end{array}$ \\
\hline Case H & $\begin{array}{l}\text { - mySPATA- Data inventory for immobile facilities (e.g. } \\
\text { building) } \\
\text { - mySPA- Data inventory for mobile facilities (e.g. } \\
\text { furniture) }\end{array}$ \\
\hline Case & Element of Analysis: Maintenance Management System \\
\hline Case A & $\begin{array}{l}\text { - Conventional (e.g. paper-based form and unsystematic } \\
\text { database) }\end{array}$ \\
\hline Case B & $\begin{array}{l}\text { - Conventional (e.g. paper-based form and unsystematic } \\
\text { database) }\end{array}$ \\
\hline Case C & $\begin{array}{l}\text { - Conventional (e.g. paper-based form and unsystematic } \\
\text { database) }\end{array}$ \\
\hline Case D & $\begin{array}{l}\text { - Conventional (e.g. paper-based form and unsystematic } \\
\text { database) }\end{array}$ \\
\hline Case E & $\begin{array}{l}\text { - Conventional (e.g. paper-based form and unsystematic } \\
\text { database) }\end{array}$ \\
\hline Case F & $\begin{array}{l}\text { - Conventional (e.g. paper-based form and unsystematic } \\
\text { database) and under DLP }\end{array}$ \\
\hline Case $\mathrm{G}$ & $\begin{array}{l}\text { - Conventional (e.g. paper-based form and unsystematic } \\
\text { database) and under DLP }\end{array}$ \\
\hline Case H & $\begin{array}{l}\text { - Conventional (e.g. paper-based form and unsystematic } \\
\text { database) and under DLP }\end{array}$ \\
\hline
\end{tabular}

Note:

DLP: Defect Liability Period

Case A: Ibrahim Sultan Polytechnic (PIS)

\section{(a) Maintenance Management Problems}

The maintenance management practices in this Polytech nic had used conventional method such as paper-based for $\mathrm{m}$ in managing the building maintenance. The maintenance processes were concerned on planning, surveying, procure ment, supervision and handover project. There were severa 1 problems identified in this Polytechnic:
- Nonspecific complaint: The complainer interpreted the defect information with general perception. As an example, the report informed that there was a damaged pipe valve at Block A. However, upon inspection, the actual defect was a leaked pipe. A respondent explained the nonspecific complaint as the quote below:

"Sometimes the reported defect is not vague, therefore the technician has to inspect the defect comprehensively" (Respondent of Case A).

The quotation above is same regarding to research made by [23].

- Time Gap of Building Repairs: The technician was unable to identify the building defects based on the customer complaint and needed to inspect the defect at the site location. This affected the time taken for maintenance planning execution.

- Limited budgets: There were many departments at the Polytechnic such as Department of Civil, Mechanical and Electrical Engineering. The budget deficiency was due to the upgrading of these building facilities. Besides, the unspecified database using the conventional method causing them to overlook for the maintenance planning. The maintenance management staff also found it difficult to calculate the budget allocation for the particular facility because of the unspecified information on the customer complaint.

- Less Competent manpower: The manpower consisted of technician to perform the building inspection at the Polytechnic. The engineer and assistant engineer did not gain the specific explanation of defect that was described in the general perception. At the same time, defect repetition also occurred due to the technician's failure to identify the actual problem at site location.

\section{(b) Approaches to Address Problems}

The cases of defect repetition and vandalism were freque nt at hostel. A few students had cause enormous damage by hitting the smoke detector for them to smoke in their room. A respondent explained the extended action of vandalism a $\mathrm{s}$ the quote below:

"We organised the control system where the staff have $r$ esponsibility for monitoring the particular facility to impro ve the vandalism problems" (Respondent of Case A).

The quotation above is same regarding to research made by [23].

Apart from punishing the students, the maintenance man agement staff had to allocate the budget in the maintenance planning. Meanwhile, the old structure building contribute $\mathrm{d}$ to the issue of defect repetition such as leaked pipe. The a pproach was to replace the old material (e.g. timber) with st rong material (e.g. heavy steel). This was to ensure the mat erial's durability and prevent it from being easily damaged. The building improvement with the specific material repla cement was executed at this Polytechnic.

\section{(c) ICT Implementation}

The technology systems used in managing maintenance 
were 'mySPATA' and 'mySPA' for data inventory at the P olytechnic. Both of these systems were developed by the $\mathrm{P}$ ublic Work Department (PWD) and Malaysian Administrat ive Modernisation and Management Planning Unit (MAM PU) to improve the inventory management of facility. The systems were to record the inventory number, equipment, $\mathrm{d}$ epartment location, building level including the room numb er into the database system. The maintenance management staff were not required to contact the complainer to clarify $t$ he information on particular defect and location. These syst ems had enabled the data inventory to be accessed for furth er corroboration in maintaining the building defect effectiv ely.

\section{(d) Maintenance Management System}

The current maintenance management system was condu cted manually using paper-based form in managing the mai ntenance processes. 'mySPATA' and 'mySPA' application $s$ were also conducted in the same way. The interviewees $r$ ecommended that the system could be improved through pa perless office in performing the building maintenance at th e Polytechnic.

\section{Case B: Sultan Salahuddin Abdul Aziz Shah Polytechnic} (PSA)

\section{(a) Maintenance Management Problems}

The maintenance management process was implemented by using the conventional method such as paper-based for $\mathrm{m}$ and email system at the Polytechnic. The assistant engin eer had identified certain problems involved in the mainten ance management as follows:

- Less competent manpower: The defect repetition was common at the Polytechnic. The building facility was old and had long life span of services since it began its operation in July 1997. In addition, the number of students had increased every year and presently, there were 6000 students. Defect repetition was due to student's vandalisms including the lack of technician's competencies to find out the causes of defect. The time gap of building repairs also affected to the budget allocated for the Polytechnic.

\section{(b) Approaches to Address Problems}

The training courses were carried out for the technicians to enhance their skills in the maintenance management prac tices. The engineer also took other approaches with the def ect repetition including replacing the old material (e.g. timb er) with strong material (e.g. heavy steel) to the building fa cility.

\section{(c) ICT Implementation}

Generally, this Polytechnic utilised email system and pa per-based form in managing complaints. Furthermore, 'my SPATA' and 'mySPA' were also used to improve the inve ntory. However, the assistant engineer suggested that the $p$ aper-based could be replaced with the electronic form with computer network.

\section{(d) Maintenance Management System}

In this Polytechnic, the conventional process was undert aken in the maintenance management system. A responden t described the conventional process as the quote below:

"The complaint is sent through paper-based form with the systematic system, though it is a conventional tool" (Respondent of Case B). The quotation above is same regarding to research made by [23].

\section{Case C: Port Dickson Polytechnic (PPD)}

\section{(a) Maintenance Management Problems}

The maintenance management process was manually co nducted where the paper-based form and email system wer e used. The assistant engineer indicated several problems $i$ $\mathrm{n}$ managing the maintenance processes as follows:

- Nonspecific complaint: The defect findings from the inspection were different from the customer complaint. This was due to unspecific information related to the explanation of the building defect. The technician required additional time to inspect the actual defect at the site location. A respondent explained the nonspecific complaint as the quote below:

"The complainer is not more specific for the facility defect that to be reported" (Respondent of Case C).

- Time gap of building repairs: The time range for inspection had increased because of the unspecific information in the customer complaint. This is due to the fact that the customer was less technical in knowledge on the building facility defect. The technician faced the time constraints to execute quick action for the maintenance.

- Limited budgets: The allocation of budget was planned early every year. This budget covered corrective and preventive maintenance including the renovation of the building facility at the Polytechnic. The ad-hoc maintenance such as exploded cable or leaked pipe caused burden to the maintenance management staff. In addition, the staff also found it difficult to estimate the budget expenses for many departments due to mishandling and undelivered complaint reports.

- Less competent manpower: The engineer and assistant engineer found less information on the building defect identification from the technician. In addition, the extended time for identifying the defect in the inspection affected the costing for building maintenance. A respondent defined the weakness of manpower as the quote below:

"The technician's explanation that based on the defect findings is not clear at the facility location" (Respondent of Case C).

The quotation above is same regarding to research made by [5]. 


\section{(b) Approaches to Address Problems}

The training courses were carried out for the technician $t$ o develop their skills on the inspection of defect in the mai ntenance management practices. The assistant engineer als o took other approaches with the defect repetition such as $r$ eplacing the old material (e.g. timber) with strong material (e.g. heavy steel).

\section{(c) ICT Implementation}

This Polytechnic provided ICT tools to support the maint enance management. These include: (a) email system; (b) mySPATA; (c) mySPA. The email system was to facilitate the customer in reporting the building facility defect. The $\mathrm{i}$ mplementation of 'mySPATA' and 'mySPA' was for recor ding the data inventory including location of defect in detai 1 .

\section{(d) Maintenance Management System}

The conventional method such as paper-based form and email system was adopted to provide the maintenance ident ification, assessment, planning and execution at the Polytec hnic. The assistant engineer suggested that the paper-based form be replaced with a computerised system that has the $p$ otential to reduce the cost on the maintenance repairs at the Polytechnic.

\section{Case D: Melaka Polytechnic (PMK)}

\section{(a) Maintenance Management Problems}

The maintenance management practices used the conven tional method such as paper-based form. The online custo mer complaint, 'E-Aduan' system, facilitated the report tra nsmission without having to send the paper-based form dir ectly to the UPS office. The most significant problems face $\mathrm{d}$ by the assistant engineer were as follow:

- Less competent manpower: Mostly, two to three complaints of different building defects were identified in one day. The technician was less competent in identifying the causes of the defect for the particular facility such as substation cable at the Polytechnic. These problems affected the maintenance execution, as illustrated, during the quotation for the specific task including the selection of an appropriate contractor.

- Defect Repetition: The reason for the defect repetition was due to the maintenance assessment and student vandalism. The failure of the technician to identify the causes of the building defect had also increased the time consumed on the inspection. A respondent described the defect repetition as the quote below:

"In general, the defect repetition is followed by technician's incompetence in solving the defect problems" (Respondent of Case A and D).

The quotation above is same regarding to research made by [23] and [24].

\section{(b) Approaches to Address Problems}

The technician had conducted daily inspection to resolve the frequency of defect at the Polytechnic. The training co urses were carried out for the technician to improve their te chnical knowledge on ad-hoc and preventive maintenance $f$ or building facility. The assistant engineer had also installe $\mathrm{d}$ a signage to motivate students and Polytechnic staff for $\mathrm{c}$ onserving the building facility properly.

\section{(c) ICT Implementation}

Generally, this Polytechnic was supported by basic ICT t ools together with an information system to support the ma intenance management. These include: (a) E-Aduan Syste m; (b) mySPATA; (c) mySPA. The E-Aduan system was $\mathrm{u}$ sed to improve the management of complaint using the pap er-based form while mySPATA was used to manage the da ta inventory for immobile facilities (e.g. building). The my SPA was used for recording the data inventory of mobile fa cilities (e.g. furniture).

\section{(d) Maintenance Management System}

Melaka Polytechnic was supported by the conventional $\mathrm{p}$ rocess in maintenance management including online custo mer complaint to facilitate the customer satisfaction in repo rting defect.

\section{Case E: Merlimau Polytechnic (PMM)}

\section{(a) Maintenance Management Problems}

The maintenance management at this Polytechnic used $t$ he conventional method namely paper-based form. The bui lding facility had long life span of services and able to acco mmodate up to 5000 students. The engineer had identified problems related to the maintenance management as follow s:

- Limited Budgets: The building facility was more than 10 years old of service life span and required frequent building maintenance. The excessive budget especially on ad-hoc maintenance restricted the technician from executing the regular maintenance. The negative action of students toward building conservation was also the main reason for the budget constraints at the Polytechnic. The students did not appreciate the advantages of the building facility that provided them the comfortable place to gain knowledge at the Polytechnic. A respondent stated the limited budget factor as follow:

"The main problem is the limited budget to conduct the maintenance operation due to the low student's mentality for preserving the facilities" (Respondent of Case E).

The quotation above is same regarding to research made by [3].

\section{(b) Approaches to Address Problems}

Priority maintenance plan was used to overcome the bud get constraints for building maintenance. In addition, the en gineer had installed the signage to motivate students and $\mathrm{P}$ 
olytechnic staff to conserve the building facility properly.

\section{(c) ICT Implementation}

The 'mySPATA' and 'mySPA' were used in managing maintenance. The use of 'mySPATA' and 'mySPA' were $t$ $o$ record the inventory number, equipment, department loca tion, building level and the room number for the inspection activity.

\section{(d) Maintenance Management System}

The current maintenance management system was condu cted manually using the paper-based form. The interviewee $\mathrm{s}$ were aware of the potential to implement ICT in improvin $\mathrm{g}$ the maintenance management processes in the future.

\section{Case F: Mersing Polytechnic (PMJ)}

\section{(a) Maintenance Management Problems}

The conventional method such as paper-based form was used to manage the corrective and preventive maintenance for the building facility. The assistant engineer had identifi ed the problems involved in the maintenance management as follows:

- Less competent manpower: An example of the defect repetition was leaked pipe at the hostel. The causes for the particular building defects were unidentified by the technician and impacted the time for the inspection works. The budget constraint was due to the number of defects repetition especially on the ad-hoc maintenance for the building facility. A respondent stated the defect repetition as follow:

"The critical budget is owed on the defect repetition problems that happened at this Polytechnic" (Respondent of Case F).

The quotation above is same regarding to research made by [24].

\section{(b) Approaches to Address Problems}

The training courses were carried out for the technicians to enhance their skills in the inspection works.

\section{(c) ICT Implementation}

Generally, this Polytechnic utilised paper-based form in managing the complaints. Furthermore, 'mySPATA' and 'mySPA' were at the early stage of implementation and use $\mathrm{d}$ to assist the technician for recording the data inventory a nd location of defect in detail.

\section{(d) Maintenance Management System}

In this Polytechnic, the conventional process was undert aken in the maintenance management conducted by the mai $\mathrm{n}$ contractor as the defect liability period (DLP) was still ef fective until 2014.

Case G: Banting Polytechnic (PBS)

\section{(a) Maintenance Management Problems}

The maintenance management practices used the conven tional method such as paper-based form and verbal commu nication. The Maintenance and Development Unit (UPS) th at consisted of an assistant engineer and technicians was to manage the building facility and infrastructure that took an area less than 100 acres. The assistant engineer had identifi ed several problems in the maintenance management as foll ows:

- Verbal complaint: The customer such as student and staff reported the defect verbally without going to the UPS office. The information had not been recorded into the database and affected the budget estimated for the particular facilities. In addition, this difficulty had also affected the maintenance planning at the Polytechnic. A respondent clarified the verbal complaint as follow:

"Commonly, the complaint is made through verbal communication especially for the uncritical defect. We encountered problem to record the information as an evident in managing the maintenance operation." (Respondent of Case G).

- Defect repetition: The contractor' s work ethic was among the causes of defect repetition. Several contractors were interested in making profits. Besides, lack of skilled in the works of inspection among the technicians affected the maintenance identification for the building facility and infrastructure. The technicians took rather a long time to investigate the causes of defect of the facilities at the Polytechnic.

\section{(b) Approaches to Address Problems}

The assistant engineer had issued notice for controlling $\mathrm{t}$ he verbal complaint in reporting the defect that involved mi nor building defects. The training courses were also carried out for the technicians in improving their competencies in the maintenance assessment of building facility.

\section{(c) ICT Implementation}

This Polytechnic provided ICT tools to the support maint enance management. These include: (a) mySPATA; (b) my SPA. The 'mySPATA' and 'mySPA' were to record the da ta inventory and location of defect in detail.

\section{(d) Maintenance Management System}

The conventional method such as paper-based form was adopted as the maintenance management was still under th e main contractor due to the effective DLP until year 2014.

\section{Case H: Nilai Polytechnic (PNS)}

\section{(a) Maintenance Management Problems}

The maintenance management was executed manually $u$ sing paper-based form. The assistant engineer had identifie d some related problems as follows: 
- Lack of motivation for reporting defect: Mostly, the paper-based form was delayed for a few days due to no motivation to report defect in the actual time. The delivery delay of the defect complaint was also because of report undelivered. Therefore, the abandoned defect increased the costing on repairs for the facilities. A respondent described the defect reported as follow:

"The attitude of student caused the delay delivery of defect complaint. Sometimes, the complaint is received after the defect occurred in a long time" (Respondent of Case $\mathrm{H}$ ). The quotation above is same regarding to research made by [3].

- Nonspecific complaint: The maintenance management staff had to contact the complainer to gather the data such as the facility type and location of defect in detail because not enough information was provided. Consequently, more time was needed to conduct the maintenance planning for the facilities at the Polytechnic.

- Defect repetition: The poor quality of work by the main contractor was one of the reasons on the defect repetition problems. In addition, the quality of material used in maintaining the facilities was also the cause for the defects repetition at this Polytechnic.

\section{(b) Approaches to Address Problems}

The technician conducted the investigation to improve th e maintenance assessment for the building maintenance wo rks done by the main contractor.

\section{(c) ICT Implementation}

Generally, this Polytechnic was supported by 'mySPAT A' and 'mySPA' to manage the data inventory for the build ing facility.

\section{(d) Maintenance Management System}

This Polytechnic was supported by the conventional pro cess as the maintenance management was still under the $\mathrm{m}$ ain contractor's responsibility until July 2013.

\section{REQUIREMENTS FOR MAINTENANCE}

\section{MANAGEMENT SYSTEM}

There were many problems related to the conventional $\mathrm{m}$ ethod at the Polytechnic such as nonspecific complaint thro ugh paper-based form, limited budgets and time gap of mai ntenance repairs. The paper-based form wasted a lot of tim $\mathrm{e}$, effort and materials. The number of students and the lon $\mathrm{g}$ life span of services required an efficient management to maintain the building facility at the Polytechnic [23]. There fore, the transformation of the conventional process into th e new system is important to improve the maintenance man agement in the works of inspection and to reduce the budge $\mathrm{t}$ that allocated for maintenance repairs especially on the ad -hoc and preventive maintenance [25].

In the case studies, the engineers and assistant engineers revealed a number of shortcomings in the conventional met hod. The building defect information was insufficient to fa cilitate the maintenance management staff to handle the dat a analysis and track the complaints. The data were also ina ccurate in order to assess the size of work done and other $\mathrm{d}$ ecision making information.

The repetition of defect was frequent at Polytechnic [23]. The maintenance inspection and assessment was not able to address the building defect problems at the particular locat ion due to the less competent manpower. Furthermore, the maintenance backlogs management caused the budget to be expanded to prevent the deterioration of the building facili ty.

In this research, the development of system was intended to improve the maintenance management problems and $\mathrm{pr}$ ocesses at the Polytechnic. The processes consisted of: (1) Defect Complaint; (2) Defect Diagnosis and Assessment; (3) Preventive Maintenance; and Report Protection. The ex planation of the maintenance management processes in this system is as follows:

- Defect Complaint: The customer will provide the password to login into the complaint form (VB.Net). The password is confidential in order to provide restricted access from hackers. In the complaint form, the customer can choose the data from the list of the facility types, defect and location in details. The database system (MS Access) provides the complete information in reporting defect in the complaint form. The status of complaint can be examined by using the same password and the status is classified as 'not repaired', 'being repaired' and 'repaired' in the system.

- Defect Diagnosis and Assessment: The technician will monitor the complaint received from customers. The inspection form (VB.Net) is used by the technician to update certain data based on the building defect inspection and assessment that will be categorised into four types, namely, 'immediate repair', 'need a spare part', 'need external contractor/supplier' and 'not economical to repair'. The provided database system is to assist the technician to complete the information accurately in managing the maintenance planning. Besides, the statistics of the ad-hoc maintenance can be analysed to examine the association between the allocations relative to total maintenance budget. The building performance also can be measured through the risk of failure classification factor such as good and moderate at the Polytechnic.

- Preventive Maintenance: At this stage, the technician finds out the required information of the building facility for planning the preventive maintenance. The system is equipped with the decision making process to present the alert sign colour in the form (VB.Net) when the particular equipment is near to the date of services. The alert signs are sorted into two colours. The white colour indicated the uncritical date of service while the red colour specified the critical date of services that requires immediate action to prepare the maintenance execution. 
- Report Protection: All information of the maintenance management is sent to the database system (MS Access) with a restricted access on the personal files and documentation of the members of senior management at the Polytechnic.

Based on Figure II the programming software (e.g. Visu al Basic.Net and Microsoft Access) is used in the compone nts of the maintenance management system to describe the stages that started from complaints by students and staffs in reporting the defects at the polytechnics.
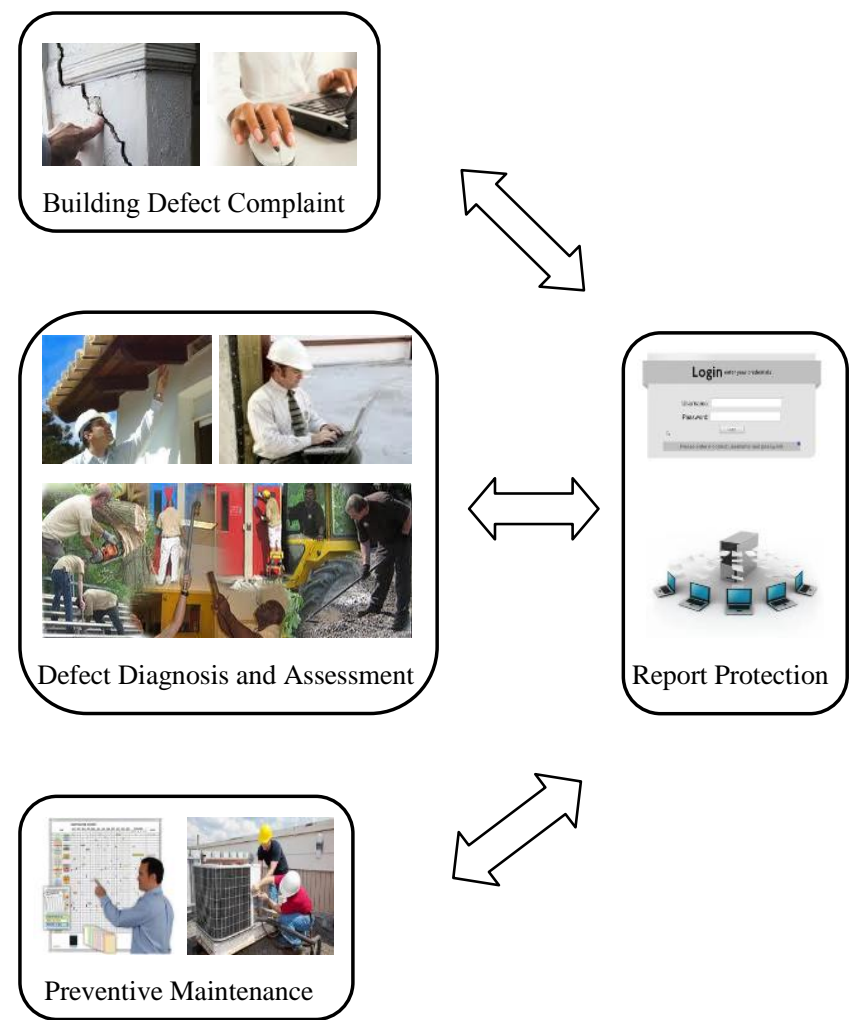

FIGURE II

COMPONENTS OF MAINTENANCE MANAGEMENT

\section{CONCLUDING REMARKS}

There is a total of eight case studies have been used to an alyse the key problems, approach to address problems, ICT implementation and maintenance management system at $p$ olytechnic. The factor of nonspecific complaint, defect rep etition, limited budgets, time gap of building repairs and le ss competent manpower are the main problems on the case studies findings. This happened in the Polytechnics which utilised the conventional method in the maintenance manag ement processes. The delay of repair is due to the inaccurat e information in the customer complaint. The suggestion fo $r$ good practices is through the implementation of ICT to re duce the defect repetition on the material used for building facility. In order to improve information adequacy in the co mplaint, the new system will be developed which provides building attributes, for instance, the facility type, defect an $\mathrm{d}$ location in detail. This database system can facilitate the $\mathrm{t}$ echnician to track complaints and assess the size of work $b$ een done in the maintenance process. Other than that, the $n$ ew system can manage budgets on ad hoc and preventive $\mathrm{m}$ aintenance effectively.

The new system development is able to integrate the rela ted information with the building diagnosis data in order to provide better maintenance assessment for identifying sym ptoms, causes and reasons of building defects. In the infor mation database, the integration of database with the decisi on making process can support the maintenance efficiency in order to reduce the data inaccuracy in reporting and anal ysing defect at the actual site location. In addition, the time consumed for building inspection can be decreased becaus e of the precise information flow plan based on the mainten ance identification process.

Regarding the above contributions, this research will con centrate on the development of a new system to integrate th e maintenance identification, assessment and planning proc esses to improve the decision making process and maintena nce management at polytechnic.

The implications of the use of new system development $i$ $\mathrm{n}$ the research are well recognised for considerably improvi ng the maintenance management practices at Polytechnic. There is substantial scope for further research, which can in clude the following:

- Integrating the new system development with other sophisticated instruments (e.g. RFID, NDT and sensor) to improve the reliability of the maintenance management processes in the new system. This integration will be able to increase the effectiveness of the system in solving building defect problems at Polytechnic for commercialisation strategy.

- The applicability of this new system development at Polytechnic is based on the current impact of maintenance management practices to support the requirement for improving the overall process of maintenance management.

\section{REFERENCES}

[1] Z. A. Akasah, S. H. Shamsuddin, I. A. Rahman, M. Alias, "School Building Maintenance Strategy: A New Management Approach", Malaysian Technical Universities Conference on Engineering and Technology (MUCET 2009), Pahang, Universiti Malaysia Pahang, pp. 1-5, 2009.

[2] O. A. Lateef, M. F. Khamidi, A. Idrus, "Building Maintenance Management in a Malaysian University Campus: A Case Study", Australasian Journal of Construction Economics and Building, Vol. 1 No. 2, pp. 76-89, 2010.

[3] M. H. M. Lazim, N. A. A Samad, "Masalah Melaporkan Kerosakan Komputer di Jabatan Teknologi Maklumat dan Komunikasi", Politeknik Tuanku Syed Sirajuddin, Politeknik Tuanku Syed Sirajuddin Digest (PTSS Digest), 2011.

[4] S. Hassan, "Developing Online Help Desk For Politeknik Tuanku Sultanah Bahiyah", Master's Thesis, Universiti Utara Malaysia, Kedah, 2010.

[5] Z. Ismail, "Maintenance Management System to Support Facilities Management at Polytechnic", Degree's Thesis, Universiti Teknologi Malaysia, Johor, 2012.

[6] C. D. O'Donoghue, J. G. Prendergast, "Implementation and Benefits of Introducing a Computerised Maintenance Management System 
Into a Textile Manufacturing Company”, Journal of Materials Proceeding Technology, Vol. 153-154 No. 2004, pp. 226-232, 2004.

[7] D. Mutia, J. Kihiu, S. Maranga, "Developing an In-house Computerised Maintenance Management System for Hospitals", Industrial Engineering Letters, Vol. 2 No. 3, pp. 1-9, 2012.

[8] E. Lecorche, G. Senecal, "Installation of a CMMS piece of software aiming to improve the maintenance strategy at Ganil", 1st Accelerator Reliability Workshop (ESRF), 2002.

[9] A. W. Labib, "A Decision Analysis Model for Maintenance Policy Selection using a CMMS", Journal of Quality in Maintenance Engineering, Vol. 10 No. 3, pp. 191-202, 2004.

[10] B. A. Najjar, "Just In Time Dynamic \& Cost-Effective Maintenance (JIT DMAINT) For More Reliable Production: A Case Study", Journal of Applied Engineering Science, Vol. 10 No.2, pp. 107-115, 2012.

[11] K. P. Liu, B. L. Luk, F. Tong, Y. T. Chan, "Application of Service Robots for Building NDT Inspection Tasks", Industrial Robot: An International Journal, Vol. 38 No. 1, pp. 58-65, 2011.

[12] S. K. Tso, T. Feng, "Robot Assisted Wall Inspection for Improved Maintenance of High-Rise Buildings", 20th International Symposium on Automation and Robotics in Construction, pp. 449455, 2003.

[13] A, Jaiswal, "Monitoring \& Evaluation of Maintenance of Building Structures Latest Techniques", UNESCO (ISTIC) \& ESCI Training Workshop, 2011.

[14] M. B. Awang, A. H. B. Mohammed, S. I. B. Abdullah, F. S. B. Abdul Shukor, "Facilities Management Competency Imperatives to Realize Polytechnic Transformation Goals", in Proceeding of the International Conference On Management (ICM 2011), Skudai, Johor Bharu, Universiti Teknologi Malaysia, pp. 480-496, 2011.

[15] E. Saghatforoush, B. Trigunarsyah, E. Too, A. Heravitorbati, "Extending Constructability Concept to include Operation and Maintenance Issues", in International Construction Business \& Management Symposium (ICBMS 2011) Proceeding, Universiti
Teknologi Malaysia, Kuala Lumpur, Queensland University of Technology, pp. 1-10, 2011.

[16] R. Razali, K. N. A. Halim K. Jusoff, "Quality Improvement of Services in Universiti Teknologi Mara Pahang from a Management Perspective", Journal of Management Science and Engineering, Vol. 5 No. 1, pp. 71-80, 2011.

[17] S. H. Zulkarnain, E. M. A. Zawawi, M. Y. A. Rahman, N. K. F. Mustafa, "A Review of Critical Success Factor in Building Maintenance Management Practice for University Sector", Journal of The World Academy of Science, Engineering and Technology, Vol. 34 No. 77, pp. 195-199, 2011.

[18] B. Mikkelsen, "Methods for Development Work and Research: A New Guide for Practitioners", $2^{\text {nd }} E d$, SAGE Publications, Inc, New Delhi, India, 2005.

[19] U. Flick, "An Introduction to Qualitative Research", $4^{\text {th }}$ Ed, SAGE Publications, Inc, London, UK, 2009.

[20] D. Leonard-Barton, "A Dual Methodology for Case Studies: Synergistic Use of a Longitudinal Single Site with Replicated Multiple Sites", Journal of Organizational Science, Vol. 1 No. 3, pp. 248-266, 1990.

[21] R. K. Yin, "Case Study Research: Design and Methods", $3^{\text {rd }}$ Ed, SAGE Publications, Inc, Thousand Oaks, CA, 2003.

[22] Jabatan Pengajian Politeknik, 2013, "Senarai Politeknik KPT". Retrieved on August 22, 2013, from http://www.politeknik.edu.my/portalbpp/index.asp?pg=poli

[23] M. N. Yusof, "Inspirasi Ke Arah Kampus Politeknik Lestari", Degree's Thesis, Universiti Teknologi Malaysia, 2010.

[24] Z. Ismail, N. Kasim, "Improving Maintenance Management Practices on Conventional Method at Malaysian Polytechnic", International Conference on Technology Management, Business and Entrepreneurship 2012 (ICTMBE 2012), Melaka, Universiti Tun Hussein Onn Malaysia, pp. 432-438, 2012.

[25] D. Dukic, M. Trivunic, A. Starcev-Curcin, "Computer-Aided Building Maintenance with "BASE-FM" Program", Journal of Automation in Construction, Vol. 30, pp. 57-69, 2013. 